\title{
THE DNA BARCODING DATA AND GENETIC DISTANCE OF LEAF BEETLES (Coleoptera, Chrysomelidae) IN VIETNAM
}

\author{
Nguyen Thi Dinh \\ Institute of Ecology and Biological Resources, VAST, Vietnam
}

Received 8 June 2020, accepted 20 September 2020

\begin{abstract}
DNA barcoding is a useful tool in identifying species, biodiversity assessment, and revealing phylogenetic relationships of living organisms in the world. However, the DNA barcode data for leaf beetles in Vietnam is lacking. In this study, sixteen DNA sequences of $658 \mathrm{bp}$ of COI gene from nine species (five genera; three subfamilies) of Chrysomelidae in Vietnam were (obtained). Intra- and inter-specific diversities, and phylogenetic relationships of these species were analyzed.
\end{abstract}

Keywords: Biodiversity, COI gene, intra- and inter-species diversity, molecular identification, tropical forest.

Citation: Nguyen Thi Dinh, 2020. The dna barcoding data and genetic distance of leaf beetles (Coleoptera, Chrysomelidae) in Vietnam. Academia Journal of Biology, 42(4): 25-31. https://doi.org/10.15625/26159023/v42n4.15124

Corresponding author email: ntdinh.iebr@gmail.com

(C2020 Vietnam Academy of Science and Technology (VAST) 


\section{INTRODUCTION}

The family Chrysomelidae is one of the largest family of the order Coleoptera, with $35,000-60,000$ species in the world (Schmitt, 1996; Futuyma, 2004; Splipnski et al., 2011; Jolivet, 2015).

DNA barcoding was proposed as a method of species identification (Hebert et al., 2003). It uses a short standard fragment, 658 bp of mitochondrial cytochrome oxidase subunit I $(C O I)$, to identify the species. Obtained DNA barcoding sequences have been stored in the online databases (GenBank or BOLD), the total number of accepted and described organism species is estimated to be close to 1,900,000 (Chapman, 2009). Although approximately 8.7 million species on the planet (Mora et al., 2011), the number of species in DNA barcoding data base is still limited; only 214,288 species were recovered. Of these, 3,204 species of Chrysomelidae were recovered on BOLD (BOLDSYSTEM, accessed 15 December 2019). In Vietnam, DNA sequences of 829 bp of $C O I$ gene for 141 species Chrysomelidae in Nui Chua national park (South of Vietnam) were recorded in the online database (Nguyen \& Gómez-Zurita,
2016). Among these species, only 18 species were identified to species level by morphology (Nguyen \& Gómez-Zurita, 2017), remaining 123 morphological form were only identified to subfamily or genus level.

This study generated and submitted sixteen DNA sequences of $658 \mathrm{bp}$ of $\mathrm{COI}$ of nine species belonging to five genera of three subfamilies that were collected in several provinces in Vietnam. These are the first DNA barcoding data for those species. Phylogenetic tree, and intra- and inter- specific distances were analyzed. Furthermore, the host plant of some species were also recorded.

\section{MATERIALS AND METHODS}

\section{Sample collection and identification}

Specimens were collected by sweeping trees by bug catching net randomly along roads and by hand directly (catch specimens directly by hand without collectional tools) in six provinces in Vietnam, such as Bac Ninh, Ha Noi, Son La, Thai Nguyen, Tuyen Quang, and Kien Giang (Table 1). Specimens were captured in vials containing $96 \%$ alcohol and were labeled with sampling date, location, and collector.

Table 1. Localities and host plants of Chrysomelidae analysed in this study (morphology of those species are in Figure 2)

\begin{tabular}{|c|c|c|c|c|c|}
\hline Subfamily & Genus & Species & Locality & $\begin{array}{c}\text { No. of } \\
\text { specimens }\end{array}$ & Host plant \\
\hline \multirow{2}{*}{ Galerucinae } & \multirow{2}{*}{$\begin{array}{l}\text { Aulacophora } \\
\text { Dejean, } 1835\end{array}$} & indica (Gmelin, 1790) & Kien Giang & 01 & $\begin{array}{c}\text { Cucurbita } \\
\text { (Cucurbitaceae) }\end{array}$ \\
\hline & & mouhoti Baly, 1886 & Son La & 01 & - \\
\hline \multirow{7}{*}{ Cassidinae } & \multirow{2}{*}{$\begin{array}{l}\text { Cassida } \\
\text { Linnaeu, } 1758 \\
\end{array}$} & \multirow{2}{*}{$\begin{array}{l}\text { circumdata } \text { Herbst, } \\
1799\end{array}$} & Ha Noi & 03 & \multirow{2}{*}{$\begin{array}{c}\text { Ipomoea } \\
\text { (Convolvulaceae) } \\
\end{array}$} \\
\hline & & & Bac Ninh & 02 & \\
\hline & \multirow{4}{*}{$\begin{array}{l}\text { Aspidimorpha } \\
\text { Hope, } 1840\end{array}$} & $\begin{array}{l}\text { dorsata Fabricius, } \\
1787\end{array}$ & Tuyen Quang & 01 & \\
\hline & & \multirow{3}{*}{$\begin{array}{l}\text { furcata (Thunberg, } \\
\text { 1789) }\end{array}$} & Ha Noi & 01 & \\
\hline & & & Bac Ninh & 01 & \\
\hline & & & Kien Giang & 01 & \\
\hline & $\begin{array}{l}\text { Chiridopsis } \\
\text { Spaeth, } 1922\end{array}$ & $\begin{array}{l}\text { bowringi (Boheman, } \\
1855)\end{array}$ & Tuyen Quang & 01 & \\
\hline \multirow{4}{*}{ Criocerinae } & \multirow{4}{*}{$\begin{array}{l}\text { Lema } \\
\text { Fabricius, } \\
1798\end{array}$} & demangei Pic, 1924 & Ha Noi & 01 & \multirow{3}{*}{$\begin{array}{l}\text { Pueraria } \\
\text { (Fabaceae) }\end{array}$} \\
\hline & & \multirow{2}{*}{$\begin{array}{l}\text { saigonensis } \text { Pic, } \\
1923\end{array}$} & Son La & 01 & \\
\hline & & & Thai Nguyen & 01 & \\
\hline & & $\begin{array}{l}\text { praeusta (Fabricius, } \\
1792 \text { ) }\end{array}$ & Bac Ninh & 01 & - \\
\hline
\end{tabular}


In the laboratory, specimens were morphologically identified with the identification keys of Kimoto \& Gressitt (1979), Kimoto (1989, 1998), Kimoto \& Takizawa (1997), Warchalowski (2011), Nguyen \& Gómez-Zurita (2017). All the identified specimens were preserved in vials containing 96\% alcohol until DNA extraction.

\section{DNA extraction, amplification and sequencing}

Total DNA was extracted using QIAamp ${ }^{\circledR}$ DNA Investigator (QIAGEN) extraction kit from 1-3 legs of each specimen following the manufacturer's protocol. Primers LepF1 (forward direction) (5'ATTCAACCAATCATAAAGATATTGG-3') and LepR1 (Reverse direction) (5'TAAACTTCTGGATGTCCAAAAAATCA-

3') (Hebert et al., 2004) were used to amplify the COI fragment of $658 \mathrm{pb}$. Each PCR reaction mixture contained $2.5 \mu \mathrm{l}$ of $10 \mathrm{x}$ reaction buffer (Evrogen, Russia), $0.5 \mu 1$ of 10 $\mathrm{mM}$ dNTPs, $0.5 \mu \mathrm{l}$ of $10 \mu \mathrm{M}$ forward primer, $0.5 \mu \mathrm{l}$ of $10 \mu \mathrm{M}$ reverse primer, $1 \mu \mathrm{l}$ of 25 $\mathrm{mM} \mathrm{Mg} \mathrm{Mg}^{2+}, 2 \mu \mathrm{l}$ of template DNA, $0.2 \mu \mathrm{l}$ of thermostable Taq DNA polymerase (Evrogen, Russia), and $17.8 \mu$ l deionized water. The PCR regime included initial denaturation at 94 ${ }^{\circ} \mathrm{C}$ for $3 \mathrm{~min}$; 35 cycles of denaturation at 94 ${ }^{\circ} \mathrm{C}$ for $30 \mathrm{~s}$, annealing at $42{ }^{\circ} \mathrm{C}$ for $40 \mathrm{~s}$, elongation at $72{ }^{\circ} \mathrm{C}$ for $60 \mathrm{~s}$; and final elongation at $72{ }^{\circ} \mathrm{C}$ for $5 \mathrm{~min}$. The PCR products were checked by $1.5 \%$ agarose gel electrophoreis and were sequenced in both directions using the BigDye Terminator v3.1 Cycle Sequencing kit (Applied Biosystems, Foster City CA, USA) with the same PCR primers. Specimens after DNA extraction were preserved in 96\% alcohol and were stored in $-4{ }^{\circ} \mathrm{C}$ at Institute of Ecology and Biological Resouces.

\section{Analyses}

Obtained DNA sequences were edited and aligned in Geneious Prime 11.1.4 version (https://www.geneious.com). The Maximum Likelihood trees were constructed using RAxML v7.0.3 for windows (Stamatakis, 2006) and Bayesian Inference (BI) analysis was also executed with MrBayes v3.2.1 (Ronquist et al., 2012). For the ML analysis, optimal ML tree was obtained with an initial step to explore the best initial rearrangement setting from a collection of 100 most parsimonious random starting trees, and a second step using these optimal settings in a multiple inference search for the best-known likelihood tree using 1,000 replicates. In BI analysis, the number of generations $(\mathrm{mcmc}$ ngen) was set to $1,000,000$, print frequency (printfreq) was 200, sample frequency (samplefreq) was 500, number of chains (nchains) was four, and the 'save branch length' information in the tree (savebrlens) was selected. To check the result of BI analysis, we used the Tracer v.1.7.1 (Rambaut, 2018): if the values of the effective sample size (ESS) got some red (or < 200) we ran mcmc ngen longer until all of the ESS values were black. We calculate posterior probabilities from remaining tree after burnin $25 \%$ of generation trees. Both methods included Pidonia ruficollis voucher BIOUG (Cerambycidae) as an out-group.

To do the species delimitation analyses, the bipartition tree that was produced from RAxML software was analyzed online by the bPTP web server (https://species.h-its.org/) (Zhang et al., 2013). We also estimated intraand inter-specific genetic distances by using Mega X v.10.0.5 (Kumar et al., 2018) with Kimura's 2-parameter model with 500 bootstrap replications.

\section{RESULTS}

Sixteen DNA sequences of the $658 \mathrm{bp}$ fragment of $\mathrm{COI}$ were obtained for the nine species (Table 1). Sequences generated in this study have been deposited in GenBank with accession number "MN845114 MN845129". Notably, the DNA barcoding sequences of nine species: Aulacophora indica, Aulacophora mouhoti, Aspidimorpha dorsata, Aspidimorpha furcata, Cassida circumdata, Chiridopsis bowringi, Lema (Lema) demangei, Lema (Lema) praeusta and Lema (Lema) saigonensis in Viet Nam were firstly recorded. 
Values of intra- and inter-specific genetic distances are presented in table 2. In this study, we could obtain intraspecific distances in three species; slightly large values were observed in Lema (Lema) saigonensis (0.06 \pm 0.01 ), but other two species show smaller (0.02, A. furcata) or zero (C. circumdata) distances. Interspecific distances range from a minimum of $0.07 \pm 0.01$ (Chiridopsis bowringi with Cassida circumdata) to a maximum $0.32 \pm 0.03$ (Chiridopsis bowringi with Lema (Lema) praeusta; Table 2). Interspecific distance of Cassida circumdata with the other species is low, ranging from $0.07 \pm 0.01$ to $0.15 \pm 0.01$, whereas the interspecific distance of Chiridopsis bowringi with species in Lema genus is high, from 0.21 \pm 0.02 to $0.32 \pm 0.03$.

Table 2. The intra- and interspecies genetic distances (Kimura's 2-parameter) and standard deviation values of Chrysomelidae in this study (intra - species genetic distances are grey boxes)

\begin{tabular}{|c|c|c|c|c|c|c|c|c|c|}
\hline Species & $\begin{array}{c}A . \\
\text { indica }\end{array}$ & $\begin{array}{c}A . \\
\text { mouhoti }\end{array}$ & $\begin{array}{c}\text { A. } \\
\text { dorsata }\end{array}$ & $\begin{array}{c}A . \\
\text { furcata }\end{array}$ & $\begin{array}{c}C . \\
\text { circumdata }\end{array}$ & $\begin{array}{c}C . \\
\text { bowringi }\end{array}$ & $\begin{array}{c}\text { L.(L.) } \\
\text { praeusta }\end{array}$ & $\begin{array}{c}\text { L. }(L .) \\
\text { saigonensis }\end{array}$ & $\begin{array}{c}L .(L .) \\
\text { demangei }\end{array}$ \\
\hline \multicolumn{10}{|l|}{ A. indica } \\
\hline A. mouhoti & $\begin{array}{c}0.16 \pm \\
0.02\end{array}$ & & & & & & & & \\
\hline A. dorsata & $\begin{array}{c}0.31 \pm \\
0.03\end{array}$ & $\begin{array}{c}0.31 \pm \\
0.03\end{array}$ & & & & & & & \\
\hline A. furcata & $\begin{array}{c}0.17 \pm \\
0.02\end{array}$ & $\begin{array}{c}0.17 \pm \\
0.02\end{array}$ & $\begin{array}{c}0.10 \pm \\
0.01\end{array}$ & 0.02 & & & & & \\
\hline $\begin{array}{l}\text { C. } \\
\text { circumdata }\end{array}$ & $\begin{array}{c}0.10 \pm \\
0.01 \\
\end{array}$ & $\begin{array}{c}0.09 \pm \\
0.01 \\
\end{array}$ & $\begin{array}{c}0.09 \pm \\
0.01 \\
\end{array}$ & $\begin{array}{c}0.13 \pm \\
0.01 \\
\end{array}$ & 0 & & & & \\
\hline C. bowringi & $\begin{array}{c}0.25 \pm \\
0.03\end{array}$ & $\begin{array}{c}0.25 \pm \\
0.03\end{array}$ & $\begin{array}{c}0.28 \pm \\
0.03\end{array}$ & $\begin{array}{c}0.15 \pm \\
0.02\end{array}$ & $\begin{array}{c}0.07 \pm \\
0.01\end{array}$ & & & & \\
\hline $\begin{array}{l}L .(L .) \\
\text { praeusta }\end{array}$ & $\begin{array}{c}0.26 \pm \\
0.03\end{array}$ & $\begin{array}{c}0.28 \pm \\
0.03\end{array}$ & $\begin{array}{c}0.31 \pm \\
0.04 \\
\end{array}$ & $\begin{array}{c}0.15 \pm \\
0.02\end{array}$ & $\begin{array}{c}0.10 \pm \\
0.01\end{array}$ & $\begin{array}{c}0.32 \pm \\
0.03\end{array}$ & & & \\
\hline $\begin{array}{l}\text { L. }(\text { L. }) \\
\text { saigonensis }\end{array}$ & $\begin{array}{c}0.21 \pm \\
0.02\end{array}$ & $\begin{array}{c}0.19 \pm \\
0.02 \\
\end{array}$ & $\begin{array}{c}0.21 \pm \\
0.02 \\
\end{array}$ & $\begin{array}{c}0.17 \pm \\
0.02 \\
\end{array}$ & $\begin{array}{c}0.15 \pm \\
0.01\end{array}$ & $\begin{array}{c}0.21 \pm \\
0.02\end{array}$ & $\begin{array}{c}0.16 \pm \\
0.02\end{array}$ & $0.06 \pm 0.01$ & \\
\hline $\begin{array}{l}L .(L .) \\
\text { demangei }\end{array}$ & $\begin{array}{c}0.29 \pm \\
0.03\end{array}$ & $\begin{array}{c}0.29 \pm \\
0.03 \\
\end{array}$ & $\begin{array}{c}0.31 \pm \\
0.03\end{array}$ & $\begin{array}{c}0.18 \pm \\
0.02\end{array}$ & $\begin{array}{c}0.10 \pm \\
0.01\end{array}$ & $\begin{array}{c}0.29 \pm \\
0.03\end{array}$ & $\begin{array}{c}0.26 \pm \\
0.03\end{array}$ & $0.16 \pm 0.02$ & \\
\hline
\end{tabular}

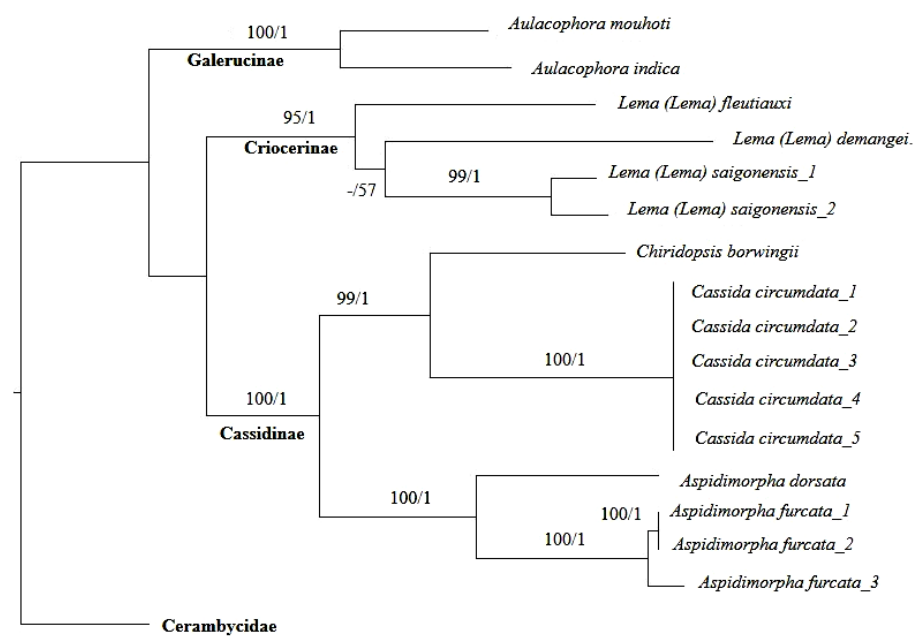

Figure 1. The phylogenetic tree obtained by Maximum likelihood (ML) method for COI gene with 1,000 bootstrap replicates based on 16 sequences of nine species and one outgroup (Pidonia ruficollis (Say, 1824). Black boxes are species which were delimited by bPTP method, each black box corresponds with one morphospecies. The numbers above branches are the support values of ML and Bayesian Inference for nodes (bootstrap and posterior probability values, respectively) 


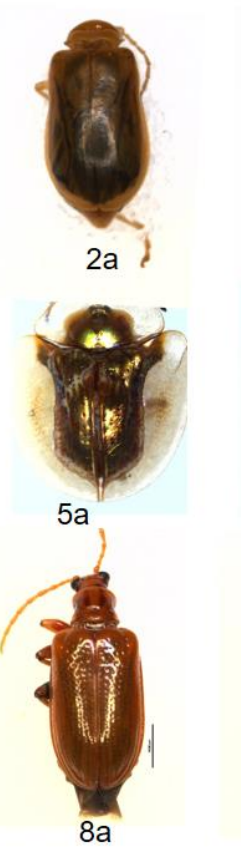

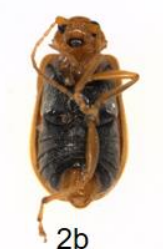
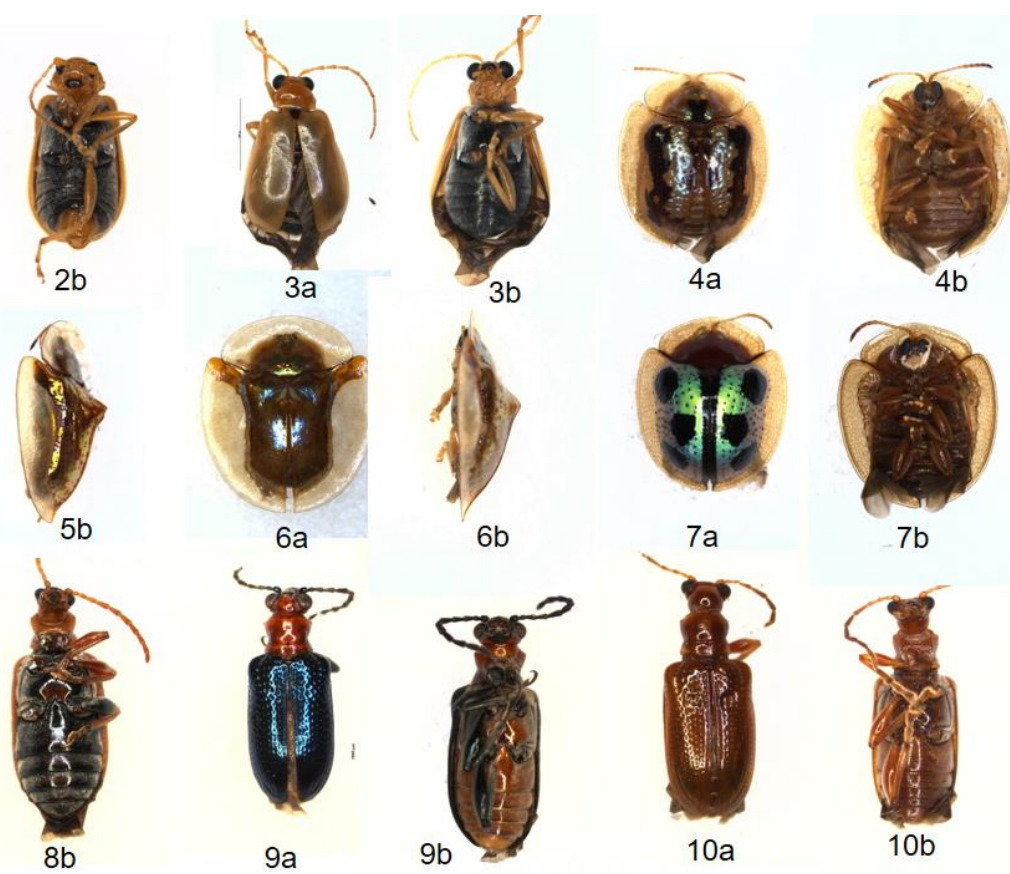

$9 a$

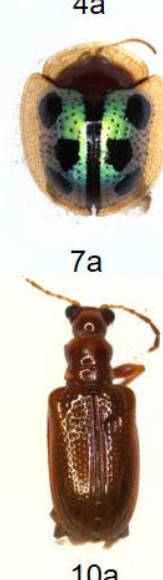

$10 a$

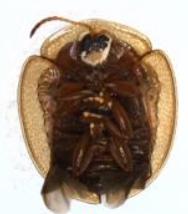

$7 \mathrm{~b}$

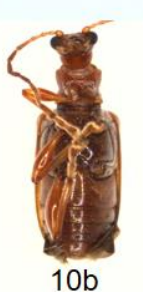

Figure 2. Morphology of species examined in this study (localities of those species as Table 1). 1: Aulacophora indica (a - dorsal view, b - abdoment view); 2: Aulacophora mouhoti (a- dorsal view, b- abdoment view); 3: Lema (Lema) praeusta (a- dorsal view, b- abdoment view); 4:

Lema (Lema) demangei (a- dorsal view, b- lateral view); 5: Lema (Lema) saigonensis (a- dorsal view, b- lateral view); 6: Chiridopsis bowringi (a- dorsal view, b- abdoment view); 7: Cassida circumdata (a- dorsal view, b- abdoment view); 8: Aspidimorpha dorsata (a- dorsal view, babdoment view); 9: Aspidimorpha furcata (a- dorsal view, b- abdoment view)

\section{DISCUSSION}

DNA barcoding is a useful tool for identifying species, providing information on specimens in different regions on the world. In this study, 16 DNA barcoding sequences of nine species examined in this work were recorded for the first time from Vietnam and five species Aulacophora mouhoti, Aspidimorpha dorsata, Chiridopsis bowringi, Lema (Lema) praeusta and Lema (Lema) demangei were recorded for the first time on the online database. Those data can be used for studies on biodiversity, ecology, and evolution if the data is complete with all data sets. Therefore, adding DNA barcode data of any species to these online resources is valuable.

We observed the low intraspecific genetic distance of Cassida circumdata. Probably it is due to the number of samples; five DNA sequences were obtained from
Cassida circumdata but the remaining species obtained only one or two sequences. These results could be related to different haplotype diversity (Magoga et al., 2018). The optimal threshold for molecular identification of Chrysomelidae is genetic distances below 3\% for species level (Magoga et al., 2018; Papadopoulou et al., 2013). The values of intra -specific distances of two species Cassida circumdata and Aspidimorpha dorsata are below 3\% (0\% and $2 \%$, respectively). The value of intraspecific distance of Lema (Lema) saigonensis is $6 \%$, higher than the optimal threshold but several research get similar result as the value of intraspecific distance of Exosoma lusitanicum (6\%) (Magoga et al., 2016) and $20.6 \%$ of Lachnaia tristigma (Lalordaire, 148) (Magoga et al., 2018). Two specimens of Lema (Lema) saigonensis were collected from two different locations (Son 
La Province and Thai Nguyen Province) and the lengths of obtained sequences are different (596 bp and $636 \mathrm{bp}$, respectively).

The number of species in this study is still small to understanding their evolution and/or phylogeography, therefore, DNA barcoding data of Chrysomelidae in Vietnam should be further researched for future study.

\section{REFERENCES}

Chapman A. D., 2009. Numbers of living species in Australia and the world. Australian Biological Resources Study, Canberra, 80 pp.

Futuyma D. J., 2004. Preface. In: Jolivet P, Santiago-Blay J. A, Schmitt M (eds) New developments in the Biology of Chrysomelidae. SPB Academic Publishing, The Hague, pp. 19-20.

Hebert P. D., Cywinska A., Ball S. L., de Waard J. R., 2003. Biological identifications through DNA barcodes. Proceedings of the Royal Society B: Biological Sciences, 270 (1512): 313-321. https://doi.org/10.1098/rspb.2002.2218

Hebert P. D., Penton, E. H., Burns, J. M., Janzen, D. H., Hallwachs W., 2004. Ten species in one: DNA barcoding reveals cryptic species in the Neotropical skipper butterfly Astraptes fulgerator. PNAS, 101: 14812-14817.

Hillis D. M., Bull J. J., 1993. An empirical test of bootstrapping as a method for assessing confidence in phylogenetic analysis. Systematic Biology, 42:182-192.

Jolivet P., 2015. Together with 30 years of symposia on Chrysomelidae! Memories and personal reflections on what we know more about leaf beetles. ZooKeys, 547: 35-61. https://doi.org/10.3897/zookeys.547.7181

Kimoto S., 1989. Chrysomelidae (Coleoptera) of Thailand, Cambodia, Laos and Vietnam. IV. Galerucinae. Esakia, 27: 1-241.

Kimoto S., 1998. Chrysomelidae (Coleoptera) of Thailand, Laos and Vietnam. V.
Cassidinae. Bulletin of the Institute of Comparative Studies of International Cultures and Societies, 21: 1-88.

Kimoto S., Gressitt, J. L., 1979. Chrysomelidae (Coleoptera) of Thailand, Cambodia, Laos and Vietnam. I. Sagrinae, Donaciinae, Zeugophorinae, Megalopodinae and Criocerinae. Pacific Insects, 20(2-3): 191-256.

Kimoto S., Takizawa H., 1997. Leaf beetles (Chrysomelidae) of Taiwan. Tokai University Press, Tokyo, $581 \mathrm{pp}$.

Kumar S., Stecher G., Li M., Knyaz C., Tamura K., 2018. MEGA X: Molecular evolutionary genetics analysis across computing platforms. Molecular Biology and Evolution, 35:1547-1549.

Magoga G., Sahin D. C., Fontaneto D., Montagna M., 2018. Barcoding of Chrysomelidae of Euro-Mediterranean area: efficiency and problematic species. Science Report, 1:13398. https://doi.org/10.1038/s41598-01831545-9

Magoga G., Sassi D., Daccordi M., Leonardi C., Mirzaei M., Regalin R., Lozzia G., Montagna M., 2016. Barcoding Chrysomelidae: a resource for taxonomy and biodiversity conservation in the Mediterranean Region. In: Jolivet P, Santiago-Blay J, Schmitt M (eds) Research on Chrysomelidae 6. ZooKeys 597: 27-38. https://doi.org/10.3897/ zookeys.597. 7241

Mora C., Tittensor D. P., Adl S., Simpson A. G., Worm B., 2011. How many species are there on Earth and in the ocean? PLoS Biol. 9(8): e1001127. https://doi.org/ 10.1371/journal.pbio.1001127

Nguyen D. T., Gómez-Zurita J., 2016. Subtle ecological gradient in the tropics triggers high species-turnover in a local geographical scale. PLoS ONE, 11(6): e0156840. https://doi.org/10.1371/ journal.pone. 0156840

Nguyen D. T., Gómez-Zurita J., 2017. Diversity and trophic ecology of the 
Monoleptites group (Chrysomelidae: Galerucinae, Luperini) in the Núi Chúa National Park (S Vietnam) with description of new species of Monolepta Chevrolat and Paleosepharia Laboissière. Journal of Asia-Pacific Entomology, 20: 65-87.

Papadopoulou A., Cardoso A., Gomez-Zurita J., 2013. Diversity and diversification of Eumolpinae (Coleoptera: Chrysomelidae) in New Caledonia. Zoological Journal of the Linnean Societ, 168: 473-495. https://doi.org/10.1111/zoj.12039

Rambaut A., Drummond A. J., Xie D., Baele G., Suchard M. A., 2018. Posterior summarisation in Bayesian phylogenetics using Tracer 1.7. Systematic Biology, 67: 901-904. https://doi.org/10.1093/sysbio/ syy032

Ronquist F., Teslenko M., van der Mark P., Ayres D. L., Darling A., Höhna S., Larget B., Liu L., Suchard M. A., Huelsenbeck, J. P., 2012. MrBayes 3.2: efficient Bayesian phylogenetic inference and model choice across a large model space. Systematic Biology, 61:539-542. https://doi.org/ 10.1093/sysbio/sys029

Schmitt M., 1996. The phylogenetic system of the Chrysomelidae - history of ideas and present state of knowledge. In: Jolivet PH, Cox ML (eds) Chrysomelidae Biology, Vol. I. The Classification, Phylogeny and Genetics. Amsterdam. SPB Academic Publishing BV, pp. 57-96.

Splipnski S. A., Leschen R. A. B., Lawrence J. F., 2011. Order Coleoptera Linnaeus, 1758. In: Zhang Z.Q. (ed) Animal biodiversity: An outline of higher-level classification and survey of taxonomic richness. Zootaxa, 3148:203-208. https://doi.org/10.1371/journal.pone.0005 502.Franz

Stamatakis A., 2006. RAxML-VI-HPC: Maximum Likelihood-based phylogenetic analyses with thousands of taxa and mixed models. Bioinformatics, 22: 2688-2690.

Warchałowski A., 2011. An introductory review of Lema Fabr. Species from Eastern and Southeastern Asia (Coleoptera: Chrysomelidae: Criocerinae). Genus, 22 (1): 29-93.

Zhang J., Kapli, P., Pavlidis P., Stamatakis A., 2013. A general species delimitation method with applications to phylogenetic placements. Bioinformatics, 29: 28692876.

https://doi.org/10.1093/ bioinformatics/btt499 